“iş, Güç” Endüstri İlişkileri ve İnsan Kaynakları Dergisi

Cilt:9 Sayı:3, Temmuz 2007, ISSN: 1303-2860

“IŞ, Güç" The Journal of Industrial Relations and Human Resources

Vol:9 No:3 July 2007, ISSN: 1303-2860

\title{
Negatif Moral Kültür, Güvensizlik Ve İşsizlik Kaygısı İlişkisi Üzerine Bir Araştırma
}

\author{
Ferhat ÖZBEK \\ Yard.Doç.Dr., İktisat Ve Girişimcilik Üniversitesi, Türk Dünyası İşletme \\ Fakültesi, İşletme Bölümü, Celal-Abad / Kırgızistan
}

\section{ÖZET}

Bir toplumun kültürel özellikleri çalışma ilişkileri ortamını etkiler. Bu etkinin düzeyi toplumdan topluma ve o toplum içerisinde farklılaşabilir. Bu çalışmada bir toplumdaki moral kültür içerisinde yer alan ve anominin göstergesi olarak ifade edilebilecek insanlara güvenmeme eğilimi, yalan söyleme ve dedikodu yapmanın, çalışma arkadaşlarına güvensizlik ve işsizlik kaygısı ile olan ilişkileri incelenmiştir. Elde edilen sonuçlara göre dedikodu yapma ve insanlara güvenmeme eğilimi, çalışma arkadaşlarına güvenmeme üzerinde etkili değişkendir. Ayrıca sonuçlar göstermektedir ki yalan söyleme ve insanlara güvenmeme eğilimi, işsizlik kaygısı üzerine etki eden değişkenler arasında yer almaktadır.

Anahtar kelimeler: Yalan, dedikodu, insanlara güvenmeme, çalışma arkadaşlarına güvenmeme, işsizlik kaygısı 


\section{ABSTRACT}

Cultural characteristics of a society affect the environment of work relationships. The level of this effect may differ from society to society and within a society. This study examines the relations between negative moral culture's propensity for not trusting people, lying \& gossiping and not trusting co-workers \& unemployment anxiety. The results indicate that gossiping and propensity for not trusting people are the variables that affect not trusting coworkers. Another conclusion of the study is that lying and propensity not trusting people affect unemployment anxiety.

Keywords: Lying, gossiping, propensity not trusting, not trusting coworkers, unemployment anxiety

\section{GiRiş}

Bir toplumun kültürü o toplum içerisinde yaşayan bütün insanlar tarafından oluşturulur ve sürekli olarak yeniden yaratııır. Kültürün bu özelliği aynı zamanda bireyler üzerinde derin izler bırakır. Toplumsal etkileşim yolu ile yaratılan kültür içerisinde varlığını sürdüren ve sosyal bir varlık olan insan ise, kendisini kültürden tam olarak soyutlayamaz ve onun kendisini şekillendirmesi karşısında etkisiz kalır. Bu derece birey üzerinde etkili olan kültür, insan yaşantısını şekillendirme yönünde mutlaka etkisini her alanda hissettirir.

İçinde bulunduğumuz dönemde çalışma yaşamında önemli değişiklikler gerçekleşmektedir. İşin niteliğinde ve yapılış biçiminde meydana gelen değişiklikler bütün çalışanları etkilemektedir. Genel olarak bu sürece "esneklik" adı verilmektedir. Esnekliğin bir türü olan sayısal esneklik, çalışanların sayısının işverenler tarafından ekonomik şartlara ve durumlara göre azaltılması ve artııılması kapsamında bir özgürlüğün sağlanması demektir. Sayısal esneklik işgörenlerde bir "işten çıkartılma kaygısı" yaratabilmektedir. Fakat bu noktada bir hususa 
dikkat etmek gerekmektedir. Sayısal esneklik aynı zamanda emek piyasasının esnekliğini de beraberinde getirebilir. Bunun bir anlamı da çalıştığı işyerinden çıkartılan işçinin, başka bir işyerinde iş bulabilmesinin kolaylaşmasıdır. Bu durumda bir sektörde veya bölgede emeğe olan talep azalınca başka bir alanda artmış olacak ve yaşanan işsizlik geçici süreli olacaktır. Ancak yine de geçici de olsa işsiz kalmak bütün işçiler için bir olumsuzluğu ifade etmektedir. Bu çalışmada ise, çalışanların işsiz kalma korkularını etkileyen bağımsız değişkenler olarak insanlara güvenmeme eğilimi, yalan ve dedikodu ile demografik faktörler ele alınmıştır.

$\mathrm{Bu}$ değişiklikler karşısında işgörenler kendilerini daha da güvensiz bir ortam içerisinde bulmaktadırlar. Bu durum, işgörenlerin yöneticilerine karşı şüphe ile yaklaşmalarına yol açmaktadır. Bu çerçevede güven ön plana çıkmakta ve onunla ile ilgili olarak yapılan araştırmalar artmaktadır. Çalışma bu açıdan düşünülecek olursa, çalışanların yönetime güven duymamasının işsizlik kaygısı üzerine etkilerini görme açısından önem taşımaktadır.

\section{ESKI KOMÜNIST BLOĞU ÜLKELERDE GENEL SOSYO- EKONOMIK DURUM}

Çalışmanın uygulamasının yapıldığı mekân eski Sovyet Sosyalist Cumhuriyetler Birliği (SSCB) ülkelerinden olan Kırgızistan'dır. Bu nedenle SSCB ülkelerindeki temel toplumsal özelliklere değinmek gerekmektedir. Bu konuda çalışma yapan önde gelen siyaset bilimci Fukuyama, $(1998,319)$ komünizm gibi totaliter projelerde, bağımsız sivil toplumun yok edildiğini ve merkezinde devletin olduğu yeni bir sosyalist topluluğun yaratıldığını söylemiştir. Sovyetler Birliği'nin mimarı Rusya aynı zamanda kültürel deterministlere göre hoşgörüsüz ve otoriter bir 
ülke olarak ifade edilirken, (Cushman, 1997, 1133) Fukuyama (1998, $319)$ için bu topluluk aynı zamanda yapaydır ve gerçeklikten yoksundur.

Fukuyama'ya $(1998,319)$ göre sosyalist sistem çökünce, ailenin ve etnik grupların veya çeteler tarafından oluşturulan suç topluluklarııın dışında hiçbir alternatif sivil örgütün olmadığı ortaya çıkmıştır. O'na göre bu tür topluluklarda güven düzeyi de oldukça düşüktür.

Sosyalist rejim içerisinde uzun yıllar boyu işsizlik kaygısını pek hissetmeyen ve yaşamı bir şekilde çalışma açısından garanti altına alınan bireyler, sistemin sona ermesi ile birlikte bir anda kendilerini rekabetçi bir ortamda bulmuşlardır. Çünkü devlet otoritesi bireylere doğrudan iş vermemekte, iş bulma ve işte tutunma tamamen bireyin çabasına ve işverenin onayı ile gerçekleşmektedir. Geçiş süreci içerisinde olan ülkelerde bu durum kendisini açık bir şekilde göstermektedir. Ayrıca bu ülkeler işsizlik ve yoksulluk kıskacıdadırlar. Örneğin Dünya Bankası'nın verilerine göre Kırgızistan'da günde 4 Amerikan dolarının altında yaşamaya çalışan insanların oranı 19961999 verilerine göre \%88'dir. (UNDP, 2005, 266-269) Bu ülkedeki genel işsizlik oranı \%10 ve uzun süreli işsizlik oranı \%4'tür. 2006 yılı verilerine göre toplam nüfusu 5,2 milyon olan Kırgızistan'ın nüfusunun \%33'ü şehirde yaşamaktadır. Kırgızistan'da kişi başına düşen GSMH 416 Amerikan dolarıdır ve kişi başına düşen gelirde Kırgızistan dünya sıralamasında 109. durumdadır. Bu ülkedeki ulusal yoksulluk oranı ise $\% 47,6$ 'dır. (UNDP, 2006)

Delhey (2002, 6-7) Doğu ve Merkezi Avrupa'daki komünist sistem içerisinde kişisel sosyal ağların oldukça önemli olduğunu, bu ülkelerde yaşayanların az bulunan kaynaklar ve hizmetler ile günlük intiyaçlarını karşılamaya çalışan özel ilişki biçimleri oluşturduklarını belirtmiştir. O'na göre eski komünist bloğu ülkelerinde genel bir şüphe 
ve güvensizlik toplumun genelini kuşatmıştı. Komünist ülkelerde sosyal güven Batı Avrupa devletleri ile karşılaştırıldığında daha düşük düzeydeydi.

Mistzal (1996, 230-231) ise benzer tespitleri Polonya için yapmıştır. Eski komünist bloğu ülkelerinden Polonya'yı, insanların eğitim düzeyinin çok yüksek olduğu buna karşın kişilerin kendilerine güvenlerinin oldukça düşük olduğu bir ülke olarak ifade etmiştir. Mistzal güven düşüklüğünün nedeni olarak da komünist yönetim biçimini göstermektedir. Çünkü komünist yönetim bireylerde endişe, engellenmişlik duygusu yaratmakta ve onların kendine güvenme duygusunu geliştirmesini engellemektedir.

\section{KÜLTÜR}

Kültür kendi içerisinde gruplandırıldığında maddi ve moral kültür şeklinde bir ayrıma gidilebilir. Maddi kültür bir toplum içerisindeki üretim araçlarını, kullanılan teknolojiyi, araç ve gereçleri kapsar. Buna karşın moral kültür, inançları, değerleri, insan ilişkilerini düzenleyen kuralları toplumda anlama sahip olan sembolleri, davranışların gerisindeki duygu ve düşünceleri veya bir toplumun zihnî arka plânını içermektedir(Bostancı, 2003, 111). Bu açıdan çalışmada kullanılan kültüre ait olan yalan söyleme, dedikodu yapma ve insanlara güvenmeme eğilimi gibi unsurları negatif moral kültürün kapsamında değerlendirmek gerekir.

Merton'a göre anomi bir toplum içerisinde normsuzluk ve kuralsızlık olarak ifade edilmektedir. (Kızılçelik, 1994, 469) Bir toplum içerisinde yalan söylemenin ve dedikodunun yaygın olarak yapılması aynı zamanda normların zayıflamasının bir işareti olarak görülebilir. Bu 
açıdan anomi bir toplumdaki veya gruptaki değerlerin bozulması veya göreli olarak eksikliği şeklinde ifade edilebilir.

\section{NEGATIF MORAL KÜLTÜR}

\section{1. Yalancılık Ve Dedikodu}

İnsanlar kendilerini zor durumdan kurtarmak için, egolarını koruyabilmek için, istedikleri bir şeyi elde etmek için vb. sebeplerle yalan söyleyebilirler. İnsanlar yalan söylediklerinde kendilerine zarar gelebilecek bir durumdan kendilerini korumuş ve psikolojik olarak rahatlatmış olabilirler. Ancak yalan söylemek kişisel bir problemi de ortaya çıkartabilir. Çünkü kişisel vicdan olgusu yalan söyleyen kişiyi sürekli rahatsız edebilir. Yalan söylemek aynı zamanda kişisel bütünlüğe de zarar verir, kişinin etkinliğini ve kendisine olan güvenini zayıflatabilir. Bununla birlikte her toplum içerisinde yalan söyleme davranışı az veya çok bulunmaktadır. Aynı zamanda kişisel ilişkilerde yalan söylemek, abartmak, dedikodu yapmak ve eleştirmek güven atmosferini tahrip eder. (Rogers, 1995, 13)

Dedikodu ise birbiri ile sosyal olarak ilişkili insanlar arasında ortaya çıkar (Abraham, 1970, 290). Eder ve Enke'ye (1991, 494) göre dedikodu ortamda bulunmayan kişi hakkında yapılan değerlendirici konuşmadır. Değerlendirme olumlu ve olumsuz yönde yapılabilir. Dedikodu informel gruplar içerisinde genel bir konuşma olarak ifade edilebilir. Fonksiyonalist yaklaşıma göre dedikodu bir sosyal kontrol aracıdır(Abraham, 1970, 290). Dedikodu sayesine bireyler diğer insanların davranışlarını sınırlandırmış olurlar. Kendisi hakkında dedikodu yapılacağını düşünen birey yapmayı istediği bazı davranışlardan vazgeçebilir. 
Hoffer'a göre (1978, 28-29) bir insanın işi meşgul olunmaya değer ise, o insan muhtemelen kendi işi ile meşgul olur. Fakat işi meşgul olunmaya değer değilse, kişi aklını kendi anlamsız işinden ayırarak başkalarının işi ile meşgul etmeye başlar. Başkasının işi ile meşgul olmak; dedikodu yapmak, kirli çamaşırlar aramak, başkasının işine burnunu sokmak, yerel, millî ve ırkî meselelere aşırı ilgi göstermek şeklinde ortaya çıkar. Böylece kendi anlamsız yaşantısından uzaklaşan kimse ya başkasının sırtına biner ya da onunla gırtlak gırtlağa gelir.

İş yaşamında ise eğer yönetici, emrinde çalışanlar ile enformasyonu zamanında ve güvenli bir şekilde paylaşırsa, her iki taraf için de olumlu sonuçlar ortaya çıkar. Bu şekildeki bir uygulama işyeri içerisinde daha az dedikodunun oluşmasını sağlar. Yöneticiler çalışanları ile enformasyon paylaşımını zamanında gerçekleştirirse, işgörenler de kendilerini daha değerli hissederler ve yönetime güvenmeye daha istekli olurlar, aksi takdirde çalışanlar üstlerinin kendilerini kandırdıklarını düşünmeye başlarlar. (Boe, 2002, 8)

\section{2. Insanlara Güvenmeme Eğilimi}

Sztompka'ya $(1999,98)$ göre bireyin diğer insanlara güvenme veya güvenmemesi geçmiş yaşantısından kaynaklanabilir. Örneğin aile içerisindeki erken sosyalleşme döneminde, içten, sıcak ve itimada dayanan güven verilmesi söz konusudur. Bireye gösterilen bakım, yapılan yardım etme ve empati kurma şeklindeki davranışlar güveni oluşturan unsurlar arasında yer almaktadır. Birey çok güvenli bir yaşam sürdürememişse insanlara karşı daha temkinli olmayı, onlara pek güvenmemeyi deneyimleri ile öğrenecektir. (Karaman, 2003, 203)

Bireyin içerisinde yaşadığı çevreye karşı duymuş olduğu güvensizliğin gerisinde diğer kişiler hakkında bilgi sahibi olmamak ve o 
kişiyle herhangi bir deneyim yaşamamış olmak gösterilebilir(Dean, 1998, 348). Bu durumda birey güveninin kötüye kullanılmasından korkmaktadır. Eğer bir insan diğer insanın güvenini kötüye kullanacağını düşünüyorsa ona asla güvenmemeyi seçer. (Buskens, 2002, 47)

\section{NEGATIF ÇALIŞMA ORTAMI}

\section{1. Çalışma Arkadaşlarına Güvensizlik}

Bir işletmede birlikte çalışmak zorunda olan insanlar birbirlerine güveniyorlarsa, o işi yürütmenin maliyeti daha az olacaktır(Fukuyama, 1998, 38). Eğer güvenmiyorlarsa bu maliyetler yükselecektir. Güven olmadığında bir işletme mutsuz ücretli çalışanlardan ve savunmacı yöneticilerden ibaret bir gruba dönüşür. Böyle bir ortamda insanlar işlerini yaparlar ama fikirlerini, coşkularını ve ruhlarını ortaya koymazlar. Güven olmadığında işletme bir topluluk olmaktan çıkar, yerini herkesin herkesle mücadele ettiği yıkıcı bir ortam alır. (Solomon, 2001, 18)

\section{2. İssizlik Kaygısı}

Modern yaşam ile beraber geleneklerinden kopan ve yeni değerleri benimsemek zorunda bırakılan bireyler için yaşam eskisine göre daha kaygı verici hale gelmiştir. Çünkü artık bireyin çalışması, iş bulması ve elde ettiği gelir ile yaşamını sürdürmesi gerekmektedir. Bu durumda çalışma birey için zorunlu hale gelmiştir.

Bir kişinin çalışmak istemesi ve çalışabilecek durumda olmasına karşılık iş bulamaması da işsizlik (Long, 1942, 4) olarak ifade edilmektedir. İşsizlik, kişinin duygusal sağlığı için risk ve tehlike içeren bir durumdur. İşsizliğin duygusal olarak kişi üzerinde yıkıcı sonuçları bulunmaktadır. Bunlar arasında depresyon, endişe, düşük kendine saygı, yaşamın kendi kontrolünde olmadığını düşünmek, kişisel 
ilişkilerde zorlanmak(Darity, 1996, 122) aile stresi ve düzensizlik (Thomas, 1980, 517) gösterilebilir. Eğer çalışanlar işsizlik kaygısını bulundukları kurum içerisinde yoğun bir şekilde hissediyorlarsa o örgütte güvenin varlığından bahsedilemez.

\section{ARAŞTIRMA HIPOTEZLERI}

Eğer bir işyeri içerisinde bulunanlar birbirlerine güvenmiyorlarsa, kendi yaşamları için olumsuz bir durumla karşılaşmamak için büyük bir çaba harcarlar(Weckert, 1999). Zaman ve enerjilerini yararlı işlere yoğunlaştırmak ve verimli olmaya çalışmak yerine, kendilerini korumak ve kendilerine zarar gelmemesi için harcarlar. Güvensiz bir çalışma ortamı duygusu, bireyde depresyon, stres, düşük örgütsel bağlılık ve önemli zihinsel sağlık problemleri ortaya çıkartarak bireyin iş performansı üzerinde olumsuz etki yapar(Darity, 1996, 125).

Güven, yalan söyleme ve dedikodu ile azalır. Kendisi hakkında dedikodu yapıldığını düşünen, bu dedikoduların işini olumsuz etkileyeceği fikrine kapılabilir ve diğer insanlara güvenme eğilimi azalır. Aynı şekilde bir topluluk içerisinde yalan söylemenin doğal olarak görülmesi güven ortamını zedelemektedir. Yalan söyleme ve dedikodu yapma aynı zamanda çalışma ortamını da olumsuz etkiler. Bu üç olumsuz eğilim çalışma arkadaşlarına güvensizliğe yol açabilir. Dolayısı ile araştırmanın ikinci hipotezi şu şekildedir;

Hipotez 1: Yalan söyleme, dedikodu yapma ve insanlara güvenmeme eğilimi çalışma arkadaşlarına güvensizlik üzerinde etkilidir. 


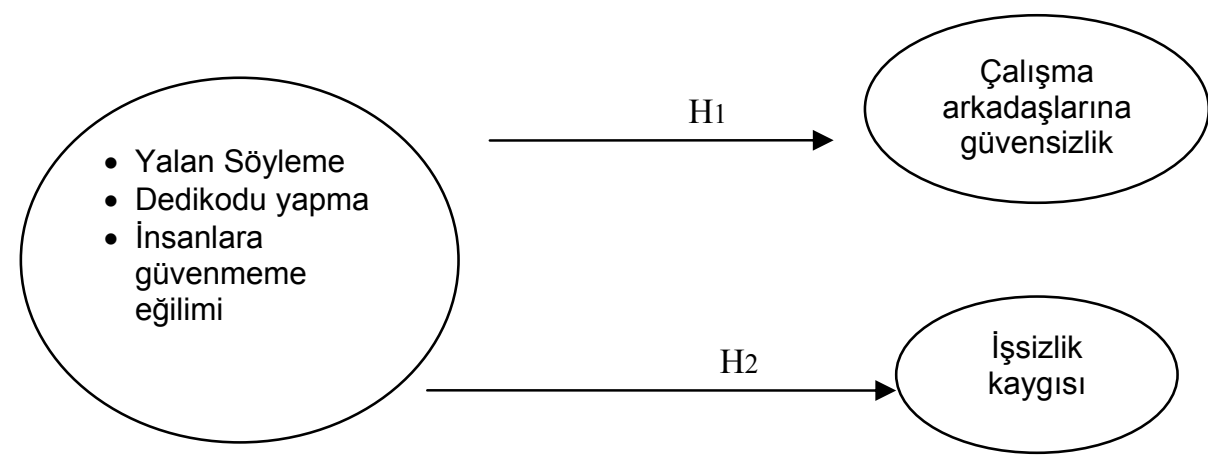

\section{ŞEKIL 1: ARAŞTIRMA MODELI}

Negatif moral kültür kapsamı içerisinde değerlendirilebilecek bu unsurlar aynı zamanda bireyin işsizlik kaygısının artmasına yol açacaktır. Bu bağlamda araştırmanın üçüncü hipotezi;

Hipotez 2: Yalan söyleme, dedikodu yapma ve insanlara güvenmeme eğilimi, işsizlik kaygısı üzerinde etkilidir.

\section{6. ÇALIŞMANIN METODOLOJISI}

Çalışmada toplam beş adet ölçek kullanılmıştır. Kullanılan ölçeklerin geliştirilmesinde daha önceden yapılan çalışmalardan faydalanılmış ve mümkün olduğunca genel ifadelere yer verilmeye çalışılmıştır. Ölçeklerin güvenilirliği ortalama kabul edilebilirlik derecesindedir. Ölçeklere ilişkin faktör analizi yapılmış ve düşük faktör yüküne sahip olan ifadeler ölçeklerden çıkartılmıştır. Değişkenler ve faktörlerle ilgili olarak Pearson korelasyon analizi ve regresyon analizi yapılmıştır.

İstatistiksel anlamda bir değişkenin değerleri değişirken buna bağlı olarak diğer değişkenin değerleri de değişiyorsa bu iki değişken arasında bir ilişki olduğu söylenilebilir. (Yüzer, 2004, 153) Değişkenler arasındaki ilişkiyi anlayabilmede regresyon ve korelasyon analizi yapılır. Regresyon metodu bir değişkenin diğer değişkene ne ölçüde dayandığını açıklama amacını güder. (Freedman, 1991, 149) Bu çalışmada tercih edilen regresyon türü doğrusal regresyondur. Doğrusal 
regresyonu uygulayabilmek için değişkenler arasında ilişkinin de doğrusal olması gerekmektedir. (Serper, 2000, 218)

\section{DATA AZALTILMASI VE INDEKS GELIŞIMi}

Toplam olarak 14 maddeden oluşan indeks Celalabat şehrinde çalışan tekstil sektöründe faaliyet gösteren fabrika işçilerine dağıtılmıştır. Bu 14 maddeyi doğrulamak için faktör analizi yöntemine başvurulmuştur. Genel olarak faktör analizinin yapılması faktör yüklerinden yola çıkılarak gerçekleştirilir(Scott, 1969, 719). Bu çalışmada yapılan faktör analizi 3 aşamadan oluşmaktadır. İlk olarak bütün değişkenlere ilişkin korelasyon matrisi hesaplanmıştır. İkinci olarak faktör çıkartma yöntemine başvurulmuştur. Rotasyon metodu olarak ölçeklerin belli başlı bileşenlerinin Kaiser Normalization Varimax ve Promax faktör analizleri tercih edilmiştir.

Negatif moral kültüre ait toplam 9 maddeden 2'si ("tanımadığım insanlara güvenmemem" ve "doğruyu söylemek her zaman iyidir") düşük faktör yüküne sahip olduğu için ölçekten çıkartılmış ve madde sayısı 7'ye düşürülmüştür.

\section{TABLO 1: NEGATIF MORAL KÜLTÜRE AIT FAKTÖR ANALIZi}

\section{Değişkenler \\ Varimax rotasyon}

1. Bence insanların arada sırada yalan söylemeleri normaldir.

2. Bana zarar geleceğini bildiğim zamanlar kendimi korumak için yalan söylediğim olmuştur.

3. Bir insan bana bir şey söylediğinde hemen onun yalan söyleyebileceği ihtimalini de göz önünde bulundururum.

4.Hiç kimseye güvenmem.

5. İnsanlara güven olmaz.

6. Dedikodunun çok yapıldığı ortamlarda insanlar birbirine güvenemez.

7. Dedikoducu bir toplumda yaşıyoruz.

\section{Yalan söyleme \\ İnsanlara güvenmeme \\ Dedikodu}

0,48

0,60

0,67

0,79

Eigenvalue değeri

1,49

1,46

0,21

0,20

0,84

0,62 


\section{Promax rotasyon}

1. Bence insanların arada sırada ,567 yalan söylemeleri normaldir.

2. Bana zarar geleceğini bildiğim ,819

zamanlar kendimi korumak için yalan söylediğim olmuştur.

3. Bir insan bana bir şey 0,70 söylediğinde hemen onun yalan söyleyebileceği intimalini de göz önünde bulundururum.

4. Hiç kimseye güvenmem. $\quad 0,83$

5. İnsanlara güven olmaz.

0,81

6. Dedikodunun çok yapıldığı ortamlarda insanlar birbirine güvenemez.

7. Dedikoducu bir toplumda yaşıyoruz.

Eigenvalue değeri

Açıklanan varyans

Toplan açıklanan varyans
1,57

0,26

0,62
0,85

0,70

1,47

0,17

Faktör içi korelasyon

Yalan

Dedikodu

0,09

Tablo 1 ve 2'de negatif moral kültür ve negatif çalışma ortamına ait faktör yükleri, eigenvalue değerleri, her bir faktörün açıklanan varyansı, toplam açıklanan varyans ve faktör içi korelâsyonlar görülmektedir.

Tablo 1'e bakıldığında varimax ve promax rotasyon ile 3 adet açık bir şekilde tanımlanabilen faktör ile toplam varyansın \%62'si açıklanmaktadır. Varimax ve Promax rotasyon maddelerin düzgün bir şekilde belirtilen faktörlere yüklendiğini göstermektedir. Faktör içi korelâsyonlar çok küçük ve önemsiz ve bu üç faktör birbirinden bağımsızdır. Genel olarak bu üç faktörün negatif moral kültürü iyi bir şekilde ölçtüğü ifade edilebilir. 
TABLO 2: NEGATIF ÇALIŞMA ORTAMINA İLIŞKIN FAKTÖR ANALIZI

\section{Değişkenler}

Varimax rotasyon

1. Yönetimin beni işten çıkartmasından kaygı duyuyorum.

2. Eğer çalıştı̆̆ım şirketten çıkartılırsam tekrar iş bulamayacağımdan kaygılanıyorum.

3. Bende gelecek korkusu bulunmaktadır.

4. Çalışma arkadaşlarımın bana karşı dürüst davranmamaları, işten çıkarılma kaygısı duymama neden oluyor.

5. Çalışma arkadaşlarımın kendi çıkarları için örgüt yöneticilerine karşı benim hakkımda olumsuz konuşabilecekleri endişesini taşıyorum.

Eigenvalue değeri Açıklanan varyans

Toplan açıklanan varyans

\section{Promax rotasyon}

1. Yönetimin beni işten çıkartmasından kaygı duyuyorum.

2. Eğer çalıştı̆̆ım şirketten çıkartılırsam tekrar iş bulamayacağımdan kaygılanıyorum.

3. Bende gelecek korkusu bulunmaktadır.

4. Çalışma arkadaşlarımın bana karşı dürüst davranmamaları, işten çıkarılma kaygısı duymama neden oluyor.

5. Çalışma arkadaşlarımın kendi çıkarları için örgüt yöneticilerine karşı benim hakkımda olumsuz konuşabilecekleri endişesini taşıyorum.

Eigenvalue değeri Açıklanan varyans

Toplan açıklanan varyans
İşsizlik kaygısı

0,818

0,823

0,677

0,870

0,730

$\begin{array}{ll}1,88 & 1,39 \\ 0,37 & 0,27 \\ 0,65 & \end{array}$

,840

,844

, 655

, 710

,904

$2,03 \quad 1,56$

$0,44 \quad 0,21$

0,65

Faktör içi korelasyon

Çalışma arkadaşlarına güvensizlik

0,33 
Tablo 2'de varimax ve promax rotasyon ile 2 adet açık bir şekilde tanımlanabilen faktör ile toplam varyansın \%65'i açıklanmaktadır. Varimax ve promax rotasyonu maddelerin düzgün bir şekilde belirtilen fakötrlere yüklendiğini göstermektedir. Faktör içi korelâsyon düşük kabul edilebilecek seviyededir. Bu iki faktörün kısmen birbirinden bağımsız olduğu ifade edilebilir. Dolayısı ile bu iki faktörün negatif çalışma ortamını iyi bir şekilde ölçtüğü ifade edilebilir.

Tablo 1 ve 2'ye göre değişkenlere ilişkin faktör yük değerleri genel olarak 0,6 ve daha üzerindedir. Faktör yük değerlerinin seçim için 0,45 ve daha yüksek olması iyi bir ölçüttür. Ancak uygulamada az sayıda madde için bu sınır değer 0,30'a kadar indirilebilir (Büyüköztürk, 2004, 118). Bu açıdan bakıldığında çalışmadaki bütün maddelerin faktör yük değerleri 0,45 'in üstündedir. Dolayısı ile çalışmada kullanılan değişkenlere ilişkin faktör yüklerinin yeterli olduğu ifade edilebilir.

\section{ARAŞTIRMADA KULLANILAN ÖLÇEKLER}

Araştırmada toplam 5 adet ölçek kullanılmıştır. Ankete katılanlara soru formu dağıtılmış ve elde edilen sonuçlara göre her bir maddenin faktör yükleri göz önünde bulundurularak toplam 5 adet ölçekte karar kılınmıştır. Ifadelerin tamamında 5'li Likert türü ölçek sıralaması "kesinlikle katımıyorum" ile "kesinlikle katılıyorum" kullanılmıştır. Kullanılan ölçeklere ilişkin açıklamalar ve güvenilirlik katsayıları aşağıda ifade edilmektedir.

\section{1. Negatif Moral Kültür}

Insanlara güvenmeme eğilimi: Diğer insanlara güvenmeme eğilimini ölçmek için 3 adet madde kullanılmış, ancak yapılan faktör analizi sonucunda düşük faktör yüküne sahip olan madde ölçekten çıkartılarak insanlara güvenmeme eğilimine ilişkin 2 madde kullanılmıştır. Ölçekte kullanılan maddelerin oluşturulmasında daha önceden yapılan çalışmalar referans alınmıştır. İlgili literatür taramasında insanlara güvenmeme eğilimi ölçeğine rastlanamadığı için daha önceden Polonya ile ilgili olarak Sztompka'nın $(1999,126)$ araştırmasında kullandığı ifade dikkate alınarak "insanların çoğu güvenilirdir" önermesinin tersi olan "insanlara güven olmaz" ifadesi ve kişisel güvensizliği vurgulayan "hiç kimseye güvenmem" ifadeleri kullanılmıştır. "Bir insan beni aldatırsa ona tekrar güvenmem" ifadesi düşük faktör yüküne sahip olduğu için ölçekten çıkartılmışır. Elde edilen sonuçlara göre bu iki maddeden oluşan ölçeğin güvenilirliği "Cronbach Alfa: 0,62" olarak gerçekleşmiştir.

Yalancılık: Yalan söyleme eğilimini ölçmek için üç adet ifade kullanılmıştır. Ölçeklerde kişinin "yalan söylemeyi doğal görmesi, 
insanın kendisini zor durumdan kurtarmak için yalan söylemeyi bir çıkış yolu olarak görmesi ve bir insan bir şey söylediğinde onun yalan söyleyebileceği intimalini de göz önünde bulundurma" ifadelerine yer verilmiştir. Elde edilen sonuçlara göre ölçeğin Cronbach Alfa değeri 0,50 olarak gerçekleşmiştir. Negatif moral kültür kapsamında değerlendirilen bu alt ölçek ilk defa kullanılmıştır.

Dedikodu yapma: Ölçek iki maddeden oluşmaktadır. Bunlardan ilki "dedikoducu bir toplumda yaşıyoruz" ifadesi ve "dedikodunun çok yapıldığı ortamlarda insanlar birbirine güvenemez" ifadeleridir. Dedikodunun olduğu bir ortamda insanlar arasındaki ilişkilerde güvensizliğin ortaya çıkması muhtemel bir olgudur. $\mathrm{Bu}$ açıdan bakıldığında dedikodunun kişiler arasındaki ilişkilerde güveni olumsuz etkileyen bir faktör olduğu söylenilebilir. Elde edilen sonuçlara göre iki maddeden oluşan ölçeğin Cronbach Alfa değeri 0,50 olarak gerçekleşmiştir. Negatif moral kültür kapsamında değerlendirilen bu alt ölçek ilk defa kullanılmıştır.

\section{2. Negatif Çalışma Ortamı}

İşsizlik kaygısı: Her çalışanın düşük veya yüksek düzeyde hissettiği işten çıkarılma kaygısı 3 madde ile ölçülmüştür. Bunlar; "çalışanın işveren tarafından işten çıkartılmaktan korkması", "eğer işten çıkartılırsa işsiz kalma korkusu" ve "gelecek korkusu" şeklindedir. Elde edilen sonuçlara göre üç maddeden oluşan ölçeğin güvenilirliği "Cronbach Alfa: 0,61" olarak gerçekleşmiştir. Bu ölçek ilk defa kullanılmıştır.

Çalışma arkadaşlarına güvensizlik: Toplam 2 adet madde ile çalışma arkadaşlarına güvensizlik ölçülmeye çalışılmıştır. Ölçek, "çalışma arkadaşlarının kendisine dürüst davranmadığını düşünmek" ve "onların yöneticilere karşı kendisi hakkında olumsuz konuşmalar yapacağını düşünmek" şeklinde 2 maddeden oluşmaktadır. Ölçeğin güvenilirliğini ifade eden Cronbach Alfa değeri 0,52 şeklindedir. Bu ölçek Pearce, Branyiczki ve Bigley'in (2000, 160) çalışmasından uyarlanmıştır.

Ölçeklerde de elde edilen sonuçlar beklenilen güvenilirlik düzeyinin altında olmasına karşın ölçeklerin ilk defa uygulanıyor olması ve daha önce eski Sovyetler Birliği ülkelerinde yapılan çalışmalarda düşük güvenilirliğe sahip olan araştırmaların bulunması gibi örneğin McFarland, Agayev ve Abalakina-Paap'ın (1992, 1009) yaptıkları çalışmada kullandıkları ölçeklere ilişkin elde edilen değerler 0,5'in altında olmasına rağmen bu alanda yapılan ilk araştırmalar olduğu için dikkate alınmaya değer görülmüştür. Yapılan çalışmanın alana ilişkin ilk 
denemelerden sayılabileceği kabul edilirse ölçeklere ilişkin güvenirlikleri bu çerçeveden değerlendirmek gerekmektedir.

\section{9. ÖRNEKLEM}

Uygulama alanı olarak Kırgızistan'ın Celalabat bölgesinde faaliyet gösteren 3 fabrikada çalışan işçiler seçilmiştir. Bu fabrikalar gıda sektöründe faaliyet göstermektedir. Toplan 200 adet anket formundan yaklaşık olarak 156 adet örneklem ile (\%76) analiz gerçekleştirilmiştir.

\section{TABLO 3: DEMOGRAFIK FAKTÖRLERE GÖRE ARAŞTIRMAYA KATILANLARIN DAĞILIMI}

\begin{tabular}{|l|l|l|l|}
\hline $\begin{array}{l}\text { Demografik } \\
\text { Faktörler }\end{array}$ & & Frekans & Yüzde \\
\hline Yaş & $18-25$ & 26 & \\
\hline & $26-35$ & 52 & 31,5 \\
\hline & $36-45$ & 49 & 29,7 \\
\hline Cinsiyet & $46-\leq$ & 38 & 23,0 \\
\hline & Erkek & 91 & 55,2 \\
\hline Eğitim Düzeyi & Kadın & 73 & 44,2 \\
\hline & İlköğretim & 45 & 27,3 \\
\hline & Lise & 108 & 65,5 \\
\hline Gelir Düzeyi & Üniversite & 11 & 6,7 \\
\hline & $0-100$ Dolar & 116 & 70,3 \\
\hline $\begin{array}{l}\text { Örgütte } \\
\text { Süreler }\end{array}$ & $101-200$ Dolar & 49 & 29,7 \\
\hline & $1-5$ Yıl & 52 & 31,5 \\
\hline & & 35 & 21,2 \\
\hline & $6-10$ Yıl & 24 & 14,5 \\
\hline & $11-15$ Yıl & 52 & 31,5 \\
\hline & $16-\leq$ & 165 & 100,0 \\
\hline & Toplam &
\end{tabular}




\section{BULGULAR}

Araştırma modeli çerçevesinde, değişkenlere ilişkin yapılan Pearson korelasyon ve doğrusal regresyon analizi sonucunda elde edilen sonuçlar ve standardize edilmiş ilişki katsayıları ile anlamlılık düzeyleri aşağıdaki tablolarda gösterilmektedir.

Tablo 4'e göre (Tablo 4'e ulaşmak için tıklayınız)farklı faktörlerin maddeleri arasında anlamlı ilişkilerin varlığı tespit edilmiştir. Örneğin insanlara güvenmeme eğiliminin (1 madde) ve çalışma arkadaşlarına güvenmeme (12. madde) arasında doğrusal anlamlı bir ilişkinin varlığı tespit edilmiştir. Buna paralel olarak 2. madde ile ve 4., 8. ve 10. madde arasında, 3. madde ile 4. ,6. 8. 10 ve 12. madde arasında pozitif yönlü ilişkiler bulunmaktadır. Özellikle 12. madde toplam 8 adet madde ile pozitif yönlü etkileşim içerisindedir. Bu durum faktörlerin birbirinden tam olarak bağımsız olmadığını göstermektedir.

Tablo 4'e göre farklı faktörlerin maddeleri arasında anlamlı ilişkilerin varlığı tespit edilmiştir. Örneğin insanlara güvenmeme eğiliminin (1 madde) ve çalışma arkadaşlarına güvenmeme (12. madde) arasında doğrusal anlamlı bir ilişkinin varlığı tespit edilmiştir. Buna paralel olarak 2. madde ile ve 4., 8. ve 10. madde arasında, 3. madde ile 4. , 6. 8. 10 ve 12. madde arasında pozitif yönlü ilişkiler bulunmaktadır. Özellikle 12. madde toplam 8 adet madde ile pozitif yönlü etkileşim içerisindedir. Bu durum faktörlerin birbirinden tam olarak bağımsız olmadığını göstermektedir.

\section{TABLO 5: ÇALIŞMA ARKADAŞLARINA GÜVENMEME BAĞIMLI DEĞiŞKENI ÜZERINDE ETKILİ OLAN BAĞIMSIZ DEĢiŞKENLERE İLIŞKİN İKILİ REGRESYON ANALİi̇ SONUÇLARI}

\begin{tabular}{lllll}
\hline Bağımsız & $\boldsymbol{R}^{\mathbf{2}}$ & Korelasyon & $\boldsymbol{F}$ & $\boldsymbol{P}$ \\
$\begin{array}{l}\text { Değişkenler } \\
\text { Insanlara }\end{array}$ & Değerleri & Katsayıları & Değerleri & Değerleri \\
$\begin{array}{l}\text { Güvenmeme Eğilimi } \\
\text { Yalan söyleme }\end{array}$ &, 027 &, 164 & 4,271 &, 040 \\
$\begin{array}{l}\text { Dedikodu Yapma } \\
\text {,005 }\end{array}$ &, 071 &, 073 &, 817 &, 367 \\
\hline
\end{tabular}


Araştırmanın birinci hipotezine göre çalışma arkadaşlarına güvensizlik üzerinde etkili olan değişkenler insanlara güvenmeme eğilimi, yalan söyleme ve dedikodu yapmadır. Elde edilen sonuçlara göre bu üç değişken içerisinde insanlara güvenmeme eğilimi ve dedikodu yapma çalışma arkadaşlarına güvensizlik ile anlamlı ve pozitif yönlü bir ilişki içerisindedir. Klasik basit bir denklem içerisinde regresyon bağımlı değişken üzerindeki açıklayıcı değişkenlerin etkilerini ortaya koymayı ifade etmektedir. (Scott, 1969, 719) Araştırma sonuçlarına göre bağımsız değişken içerisinde olan dedikodu yapma $\left(\boldsymbol{R}^{\mathbf{2}}\right.$ : ,071) insanlara güvenmeme eğilimine $\left(\boldsymbol{R}^{2}\right.$ :, 027$)$ göre çalışma arkadaşlarına güvensizlik üzerinde daha etkili bir değişkendir. Elde edilen sonuçlara göre yalan söyleme ile çalışma arkadaşlarına güvensizlik arasında anlamlı bir ilişkiye rastlanmamıştır. $(\boldsymbol{P}:, 367)$ Bununla birlikte yapılan çoklu doğrusal regresyon analizine göre ise bu üç değişken $\left(R^{2}:, 090, \beta\right.$ : ,300, F: 5,027, P:,002) çalışma arkadaşlarına güvensizlik üzerine etki etmektedir. Dolayısı ile $\mathrm{H}_{1}$ hipotezi kabul edilmiştir.

\section{TABLO 6: IŞSIZLIKK KAYGISI BAĞIMLI DEĞiŞKENI ÜZERINDE ETKILİ OLAN BAĞIMSIZ DEĞiŞKENLERE İLIŞKIN İKILİ REGRESYON ANALİi̇ SONUÇLARI}

\begin{tabular}{lllll}
\hline Bağımsız & $\boldsymbol{R}^{\mathbf{2}}$ & Korelâsyon & $\boldsymbol{F}$ & $\boldsymbol{P}$ \\
Değişkenler & Değerleri & Katsayıları & Değerleri & Değerleri \\
$\begin{array}{l}\text { Insanlara } \\
\text { Güvenmeme Eğilimi }\end{array}$ &, 037 &, 193 & 5,950 &, 016 \\
$\begin{array}{l}\text { Yalan söyleme } \\
\text { Dedikodu Yapma }\end{array}$ &, 104 &, 322 & 17,838 &, 000 \\
\hline
\end{tabular}

Tablo 6'ya göre işsizlik kaygısı ile ilişkili olduğu tahmin edilen değişkenler insanlara güvenmeme eğilimi, yalan söyleme, dedikodu yapmadır. Elde edilen sonuçlara göre insanlara güvenmeme eğilimi $\left(\mathrm{R}^{2}\right.$ : ,037, P:,016), yalan söyleme $\left(\mathrm{R}^{2}:, 104, \mathrm{P}:, 000\right)$, işsizlik kaygısı üzerinde etkili birer değişken iken, dedikodu yapma (P:,239), ile işsizlik kaygısı arasında anlamlı bir ilişkiye rastlanmamıştır. Yapılan çoklu regresyon analizine göre negatif moral kültüre ait değişkenler işsizlik kaygısı üzerine etki etmektedir. (R²: 0,124, R: 0,352, F:7,183, P:,000) Dolayısı ile $H_{2}$ hipotezi kabul edilmiştir.

\section{IŞSIZLIK KAYGISI ILE ILIŞKILI DEMOGRAFIK} FAKTÖRLERE ILIŞKIN YAPILAN ANALIZLER 
Demografik faktörler arasındaki işsizlik kaygısı ile tek anlamlı ilişki çalışma süresi ile ilgilidir. (R²: ,029 , R: ,169, F: 4,815, P:,030) Elde edilen sonuçlara göre toplam çalışma süresi arttıkça işsizlik kaygısının da arttığı sonucu ortaya çıkmıştır. Bu sonucu şu şekilde yorumlamak mümkündür. Çalışanlarda yeni işe başlayan bir kişinin genel olarak işe bağlılığının az olduğu ifade edilebilir. Yeni işe başlayan birisinin henüz çalıştığı şirketten elde etmiş olduğu pek fazla dış ve iç ödül birikimi oluşmamıştır. Çalışma süresi ilerledikçe bireyin çalıştığı örgütten elde ettiği kazançlar da artacaktır. Dolayısı ile işsiz kalmak o kişi için daha büyük bir yıkım ve istenmeyen bir durum olacaktır. Diğer demografik faktörler ile işsizlik kaygısı arasında anlamlı ilişkilere rastlanmamıştır. Dolayısı ile değişkenler arası ilişkiler tesadüfîdir. Elde edilen sonuçlara göre kadınlar (X: 3,45$)$ erkeklerden daha fazla $(3,06)$ işsizlik kaygısını hissetmektedirler. (P: ,020, F: 3, 990)

\section{SONUÇ}

Çalışma ortamı içerisinde yöneticilerin güveni tesis etmesi oldukça zor bir iştir. Çünkü insanların güvene ilişkin algılamaları genellikle onu yitirmeye başladıktan sonra ortaya çıkar. Güvenin tesis edilememesi durumunda çalışanların hissettikleri işsizlik kaygısı artacaktır. Araştırmada elde edilen sonuçlar bu fikri desteklemektedir.

Bunun yanında birlikte çalışanlar arasında güvensizliğin ortaya çıkmasını sağlayan pek çok faktör bulunmaktadır. Bu çalışmada insanlara güvenmeme eğilimi ve dedikodu yapmanın çalışma arkadaşlarına güvensizliğe yol açan faktörler içerisinde yer almaktadır.

Yine bu araştırmada insanlara güvenmeme eğilimi ve yalan söyleme işsizlik kaygısına yol açan bir değişken olduğu hipotezleri kabul edilmiştir. Demografik faktörler arasında yer alan çalışma süresi ile işsizlik kaygısı arasında anlamlı ve pozitif yönlü bir ilişkinin varlığı tespit edilmiştir.

$\mathrm{Bu}$ çalışma yönetim bilimi açısından, çalışanların gelmiş oldukları toplumun sosyal ilişkilerinin yapısının onların iş ortamına yönelik düşünce ve davranışlarını etkilediklerine ilişkin sonuçların elde edilmesi bakımından önem taşımaktadır.

\section{ARAŞTIRMANIN KISITLARI}

Sovyetler Birliği'nin kısa süre önce dağıldığı ve piyasa yapısına ilişkin oluşumun geliştiği Kırgızistan için bu çalışmanın geçiş sürecini yaşayan bir ülkede yapıldığı göz önünde bulundurulmalıdır. Çünkü hızıı bir değişim süreci içerisinde olan eski SSCB ülkelerde elde edilen sonuçlar ve değişkenlerin birbirlerini etkilemeleri zaman içerisinde farklılık arz edebilecektir. Ayrıca eski SSCB ülkelerinde komünist 
sistemin yol açtığı güvensiz sosyal ortamın etkilerine bu çalışma kapsamı içerisinde yer almamaktadır.

Yapılan araştırmada örneklem sayısının daha yüksek olması durumunda araştırmanın güvenilirliğinin daha da yükseleceği varsayılabilir. Bununla birlikte bu çalışmada ele alınan negatif moral kültürün öğeleri kapsamında yer alan diğer faktörlerin de dikkate alınması durumunda elde edilen ilişkilerin katsayılarının daha yüksek olacağı tahmin edilmektedir.

\section{YARARLANILAN KAYNAKLAR}

Abrahams, Roger D., (Jun., 1970), A Performance-Centred Approach to Gossip, Man, New Series, Vol. 5, No. 2. pp. 290-301

Boe, Tammy A., (2002) Gaining or/and Maintaining Employee Trust Whithin Service Organization, erişim: www.uwstout.edu/lib/thesis/2002/2002boet.pdf,

Buskens, Vincent, (2002) Social Network And Trust, Published By Kluver Academic Publishers, P. O., Box, 17, 3300 AA, Dordecht, The Netherland

Büyüköztürk, Şener, (2004) Veri Analizi El Kitab1, İstatistik, Araştırma Deseni SPSS Uygulamaları ve Yorum, Pegem A Yayınc1lık, Ankara

Cushman, Thomas, (Sep., 1997), Russian Culture at the Crossroads: Paradoxes of Postcommunist Consciousness by Dmitri N. Shalin, Europe-Asia Studies, Vol. 49, No. 6. pp. 1133-1134

Darity, William Jr. (Winter, 1996), Goldsmith, Arthur H. Social Psychology, Unemployment and Macroeconomics, The Journal of Economic Perspectives, Vol. 10, No. 1. pp. 121-140

Dean, James W. Jr., Brandes, Pamela, Dharwadkar, Ravi, (April 1998), Organizational Cynicism, The Academy Of Management Review, Vol. 23, No. 2, Pp. 341-352

Delhey, Jan, Newton, Kenneth, (May 2002) Who Trusts? The Origins of Social Trust in Seven Nations, Research Unit "Social Structure And Social 
Reporting",Social Science Research Center Berlin (WZB), erişim: http://skylla.wz-berlin.de/pdf/2002/iii02-402.pdf

Eder; Dona, Enke, Janet Lynne, (Aug., 1991), The Structure of Gossip: Opportunities and Constraints on Collective Expression among Adolescents, American Sociological Review, Vol. 56, No. 4., pp. 494-508

Freedman, David, vd. (1991), Statistics, W. W. Norton \& Company, New York, London

Fukuyama, Francis, (1998) Güven, Türkiye İş Bankası Kültür Yayınları, Birinci Basım, Çeviren: Ahmet Buğdaycı, Ankara

Gerardo A. Guerra and Daniel J. Zizzo, (April, 2003), Economics Of Trust In The Information Economy: Issues Of Identity, Privacy And Securtty, Bounded Rationality in Economic Behaviour (BREB) Unit, University of Oxford and Oxford Internet Institute (OII),

Hoffer, Eric, (1978), Kesin İnançlılar, Kitle Hareketlerinin Anatomisi, Tür Yayınlar1, İstanbul

Karaman, Taha, (2003), Grup Psikoterapisi Bağlamında Güvenin Gelişimi, Editör: Erdem, Ferda Sosyal Bilimlerde Güven, Vadi Yayınları, 1. Basım

Lewis, J. David, Weigert, Andrew, (1985), Trust As A Social Reality, Social Forces, Volume 63, Issue 4, pp. 967, 985,

Long, Clarence D., (Nov., 1942), The Concept of Unemployment, The Quarterly Journal of Economics, Vol. 57, No. 1. pp. 1-30

McFarland, Sam G., Agayev, Vladimir S., and Abalakina-Paap, Marina A., (1992), Authoritarianism in the Former Soviet union, Journal of personality and Social psychology, Vol. 63, No. 6, pp. 1004-1100

Mistzal, Barbara, A. (1996), Trust in Modern Sociaties, The Search For The Bases of Social Order, Polity Press, Cambridge 
Möllering, Guido, (2001) The Nature Of Trust From Georg Simmel To A Theory Of Expectation, Interpretation And Suspension, Sociology Vol. 35, No. 2, Pp. 403-420. Printed in The United Kingdom, BSA Publications Limited, erişim:

http://www.wiwiss.fu-berlin.de/w3/w3sydow/team/Moellering/sociology.pdf

Nooteboom, Bart, (2002) Trust, Forms, Foundations, Functons, Failures And Figures, Published By Edward Elgar Publishing Limited, Printed and Bound in Great Britain By Bookcraft (Bath) Ltd.

Pearce, Jone, L. Branyiczki, Imre, Bigley, Gregory A., (2000) Insufficent Bureaucracy: Trust and Commitment in Particularistic Organizations, Organization Science, Vol. 11, No. 2. Mar-Apr., pp. 148-162

Rogers, Robert W., (1995) The Psychological Contract Of Trust, Part I, Executive Department, Vol. 8, No. 1, pp. 15-19

Scott, John T. Jr., (Oct., 1969), Factor Analysis Regression Revisited, Econometrica, Vol. 37, No. 4., p. 719

Seligman, Adam B. Seligman, (Oct, 1998), Trust and Sociability: On The Limits Of Confidence And Role Expectations, American Journal Of Economics And Sociology

Serper, Özer, (2000) Uygulamalı İstatistik 2, Ezgi Kitabevi, Bursa

Solomon ,Robert C., Floreres, Fernando, (Aral1k 2001) Güven Yaratmak, BZD Yayın Ve İletişim Hizmetleri, İstanbul, MESS Yayın No : 369

Sztompka, Piotr, (1999)Trust, A Sociological Theory, Cambridge University Press

Thomas; L. Eugene, Mccabe; Berry, Esther Jane E., (Oct., 1980), Unemployment and Family Stress: A Reassessment, Family Relations, Vol. 29, No. 4, Family Stress, Copying and Adaptation. pp. 517-524 
UNDP, 2006, Human Development Report 2006, http://hdr.undp.org/hdr2006/statistics/indicators/190.html, http://hdr.undp.org/hdr2006/statistics/indicators/31.html,

United Nations Conference on Trade and Development, (2007) http://www.unctad.org/sections/ldc dir/docs//lldc-kyr.pdf

Weckert; John, (1999) Trust And Monitoring in The Workplace, Australian Institute Of Computer Ethics Conferance, July, Lilydale

Yüzer, Ali Fuat, vd., (2004), İstatistik, TC. Anadolu Üniversitesi Yayını no: 1448, Anadolu Üniversitesi Web-Ofset Tesisleri, Eskişehir 
TABLO 4: DEĞişKENLERE İLIŞKIN KORELASYON DEĞERLERì

1. Hiç kimseye güvenmem.

Ortalam Standart

a Sapma

2. İnsanlara güven olmaz.

2,9359

3. Bence insanların arada sırada yalan söylemeleri

3,2372

3,3269 normaldir.

4. Bana zarar vereceğini bildiğim zamanlar kendimi

3,2179 korumak için yalan söylediğim olmuştur.

5. Bir insan bana bir şey söylediğinde hemen onun

3,6154 yalan söyleyebileceği intimalini de göz önünde bulundururum.

6. Dedikodunun çok yapıldığı ortamlarda insanlar birbirine güvenemez.

7. Dedikoducu bir toplumda yaşıyoruz.

3,5833

3,4936

8. Yönetimin beni işten çıkartmasından kaygı

3,1346

9. Eğer çalıştı̆ı̆m şirketten çıkartıırsam tekrar iş 3,1859 bulamayacağımdan kaygılanıyorum.

10. Bende gelecek korkusu bulunmaktadır. $\quad 3,4038$

11. Çalışma arkadaşlarımın bana karşı dürüst 3,4423 davranmadıkları için işten çıkartııma kaygısını duyuyorum.

12. Çalışma arkadaşlarım kendi çıkarları için örgüt 3,3333 yöneticilerine karşı benim hakkımda olumsuz konuşabilecekleri endişesini taşıyorum.

\section{1.}

3.4

1,19504

1,13656

1,17591

, $429 * * \quad 1$

1,15260

, 041

1,2207

$, 154 \quad, 106$

1,12500

, 112

1,17942

\section{T. 6.}

8

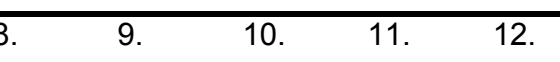

$020 \quad 096 \quad 1$

, $17113 \quad, 242^{* *}, 290^{\star *} \quad 1$

$02524 \quad 096 \quad 084 \quad, 110 \quad, 350^{* *} \quad 1$

$\begin{array}{lllllllllll}\text { 1, } 394^{* *} & , 322^{* *} & 1\end{array}$

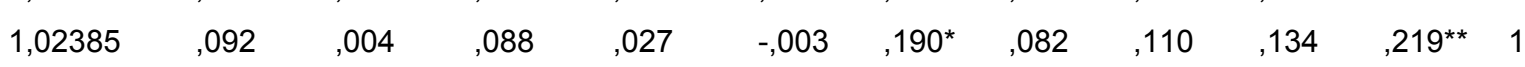

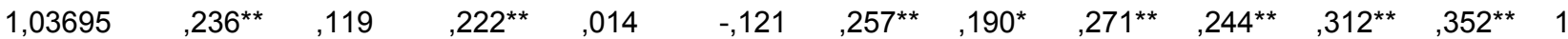

${ }^{*} \mathrm{P}<0.01 \quad{ }^{* *} \mathrm{P}<0,05$ 